\title{
Chlorophyll a, tripton, color, and light availability in a shallow tropical inner-shelf lagoon, Florida Bay, USA
}

\author{
E. J. Phlips, T. C. Lynch, S. Badylak \\ Department of Fisheries and Aquatic Sciences, University of Florida, 7922 NW 71 st Street, Gainesville, Florida 32653, USA
}

\begin{abstract}
Spatial and temporal variability of light attenuation within Florida Bay, USA was examined at 17 stations over a 1 yr period, with emphasis on the relative roles of algal and non-algal factors in the absorption of light in the water column. Four distinct regions in the bay were identified based on differences in the relationships between light extinction coefficients $\left(K_{t}\right)$, non-algal suspended solids

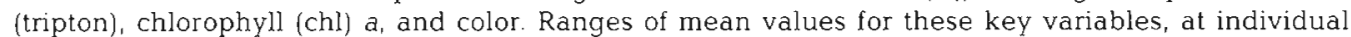
stations within the bay, were 0.66 to $2.82 \mathrm{~m}^{-1}$ for $K_{t}, 8.1$ to $30 \mathrm{~g} \mathrm{~m}^{-3}$ for tripton, 0.4 to $18.4 \mathrm{mg} \mathrm{m}^{-3}$ for chl $a$ and 1.4 to $15 \mathrm{pt}$ units for color. These results are discussed in relation to light availability for planktonic and benthic primary production in different regions of the bay and seasons of the year. The results indicate a significant potential for light limitation of seagrass colonization in certain regions of the bay due to light attenuation in the water column caused by high levels of tripton and/or phytoplankton.
\end{abstract}

KEY WORDS: Light attenuation - Tripton $\cdot$ Chlorophyll a Color $\cdot$ Seagrasses Phytoplankton

\section{INTRODUCTION}

One of the major challenges to modelling the structure and function of primary production in aquatic ecosystems is defining the nature of light availability for photosynthesis (Bannister 1974, Platt \& Jassby 1976. Wolfsy 1983, Kirk 1994). The task of describing light availability in large estuarine and lagoonal systems is complicated by spatial and temporal variability in the biogeochemical factors that contribute to light attenuation. In many estuaries non-algal suspended solids (tripton) from tidal mixing, river inflows and wave-induced sediment resuspension are major factors in light attenuation, and may cause light limitation of phytoplankton production and biomass (Malone 1977. Cadee \& Hegeman 1979, Joint \& Pomroy 1981. Oertal \& Dunstan 1981, Colijn 1982, Harding et al. 1986, Pennock \& Sharp 1986, Cloern 1987). In some estuarine environments inflows of organically stained river water cause significant color-dependent absorption of light (Kirk 1980, Granberg \& Harjula 1982, Arvola 1984, McPherson \& Miller 1987, Beaver \& Crisman 1991), as well as alteration of the spectral compo- sition of downwelling irradiance. The relative roles of different water column components in light attenuation can vary seasonally according to changes in wind energy and rainfall runoff (Kirk 1980, 1994, Vant 1990). The increasing rate of human development in watersheds of many major estuaries has added another dimension to the issue of changing light environments by altering the patterns of riverine inflow, sediment load, dissolved organic load and the trophic status of surface waters (Sorensen 1993).

The aquatic environment of Florida Bay (USA), located south of the Florida Everglades and west of the Florida Keys, is characterized by broad regional and temporal differences in water clarity. The generally shallow depth of the water column ( 0 to $4 \mathrm{~m}$ ) presents the potential for frequent resuspension of both algae and tripton. Regional differences in the properties of light attenuation in Florida Bay reflect the existence of ecologically disparate basins within the $1500 \mathrm{~km}^{2}$ area of the bay. These basins are structurally defined by a network of islands and shallow (i.e. $<0.5 \mathrm{~m}$ ) mudbanks that partially restrict water exchange between basins (Fig. 1) and impede tidal 


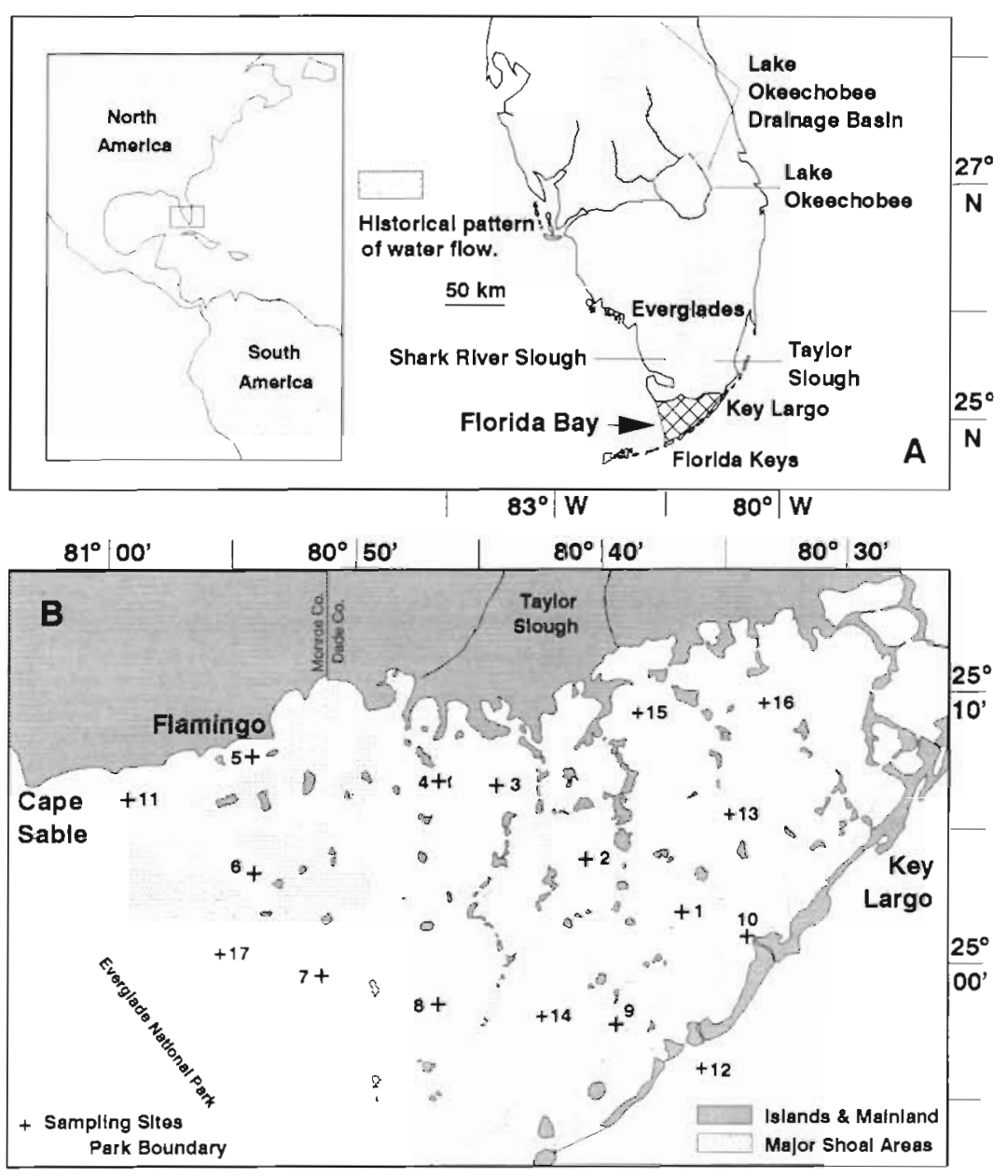

Fig. 1 (A) South Florida, USA, showing historical patterns of water flow, and (B) Florida Bay, showing location of sampling stations

Boesch et al. 1993). These changes have presumably stimulated phytoplankton biomass by increasing nutrient concentrations and water turnover times.

In contrast, other regions of Florida Bay are typified by relatively clear water conditions and low phytoplankton concentrations (Phlips \& Badylak 1995). Reductions in freshwater inflow have affected the isolated northeastern basin of the bay by reducing nutrient availability and enhancing the degree of phosphorus limitation for both planktonic and benthic primary production (Powell et al. 1989, Fourqurean et al. 1993).

Blooms of planktonic algae in Florida Bay have been implicated in the observed die-off of ecologically important seagrass populations (Robblee et al, 1991, Boesch et al. 1993). One factor which may be contributing to this die-off is the reduction in light availability for seagrasses caused by increased attenuation of light by high phytoplankton standing crops. Phytoplankton concentrations in the bay are subject to significant spatial and temporal variations (Phlips \& Badylak 1995). In one study chlorophyll a (chl a) concentrations in north-central regions of the bay were observed to average near $20 \mathrm{mg} \mathrm{m}^{-3}$, with individual values exceeding

water exchange with adjacent waters of the Gulf of Mexico and Florida Straits. The basins also have different sediment types, depths of sediment layers and benthic vegetation (Wanless 1989, Zieman et al. 1989, Fourqurean et al. 1992), all of which influence the nature and amount of suspended solids in the water column

Some regions of Florida Bay exhibit high levels of algal and/or non-algal suspended solids resulting in low light penetrance (e.g. $<0.5 \mathrm{~m}$ Secchi depths) (Phlips \& Badylak 1995). The high chlorophyll levels observed in the north-and south-central regions of the bay have been attributed by some researchers (LaPointe \& Clark 1992) to anthropogenic changes occurring in South Florida related to urban and agricultural development. Among the most prominent of these changes have been the reduction of freshwater inflow to the bay via the Everglades and general eutrophication of surface waters entering certain regions of the bay via point and non-point source inflows (LaPointe \& Clark 1992,
$40 \mathrm{mg} \mathrm{m}^{-3}$, while concentrations in the northeastern regions averaged below $2 \mathrm{mg} \mathrm{m}^{-3}$ (Phlips \& Badylak 1995). The former concentrations of chlorophyll indicate a potentially significant role for phytoplankton in light attenuation for certain regions of the bay.

This paper describes spatial and temporal variability of light attenuation within Florida Bay and examines the relative roles of algal and non-algal factors in the absorption of light by the water column. These results are discussed in relationship to light availability for planktonic and benthic primary producers in different regions of the bay, and the potential for light limitation of phytoplankton and benthic plant standing crops.

\section{METHODS}

Study sites. Florida Bay is a $1500 \mathrm{~km}^{2}$ inner-shelf lagoon located in the tropical environment off the 
southern tip of the Florida peninsula (Fig. 1A). The bay is generally shallow with depths of less than $4 \mathrm{~m}$ throughout (Fig. 2A).

Sampling regime. The data used in this paper were collected at 17 sampling stations in Florida Bay (Fig. 1B). Sampling stations were sampled once a month through the following time periods; Stns 1, 2, 3, 4 \& 10 from August 1993 to September 1994, Stns 5. 6, 7, 8 \& 9 from September 1993 to September 1994. Stns 11 \& 12 from November 1993 to September 1994, Stn 13 from December 1993 to September 1994, Stn 14 from March 1994 to September 1994, Stns 15, 16 \& 17 from May 1994 to September 1994. Water was collected using an integrated water column sampling tube, from surface to $0.1 \mathrm{~m}$ from the bottom.

Analytical methods. Chl a (corrected for pheophytin) concentrations were determined using the acetone extraction and spectrophotometric protocols described in Standard Methods (APHA 1989). Color in the water was determined from filtered $(0.3 \mu \mathrm{m})$ water using protocols described in Standard Methods (APHA 1989). Total suspended solids concentrations were determined using the methods described in Standard Methods (APHA 1989). Tripton was estimated by assuming a 1:100 ratio between chl a concentration and the dry weight of phytoplankton, and subtracting this value from the total suspended solids concentration to yield tripton concentration.

Incident irradiance, $I$, and vertical light extinction coefficient, $K_{t}\left(\mathrm{~m}^{-1}\right)$, were determined with Li-cor Instruments Inc. (Lincoln, NE, USA) submersible quantum light probes (cosine corrected) simultaneously recording surface, upwelling and downwelling light ( $\mu \mathrm{mol}$ photons $\mathrm{m}^{-2} \mathrm{~s}^{-1}$ of photosynthetically active radiation, PAR) with a data logger. Partial extinction coefficients caused by components of light attenuation were estimated using conversion factors from the literature. Light attenuation by chl-a-containing phytoplankton, $K_{c}$, was estimated by multiplying chl a concentrations by $0.058 \mathrm{~m}^{2} \mathrm{mg}^{-1}$ (McPherson \& Miller 1987). While a wide range of conversion factors is available in the literature, the latter value was used because it was based on data from an estuary within the same region of South Florida. Light attenuation by color, $K_{\mathrm{ac}}$, was estimated by multiplying pt color units by $0.014 \mathrm{pt}^{-1} \mathrm{~m}^{-1}$
(McPherson \& Miller 1987). Light attenuation by seawater, $K_{\mathrm{w}}$, was set at $0.0384 \mathrm{~m}^{-1}$ (Lorenzen 1972). Light attenuation attributable to tripton, $K_{\mathrm{b}}$, was calculated as $K_{1}-\left(K_{\mathrm{c}}+K_{\mathrm{ac}}+K_{\mathrm{w}}\right)$. Mean light availability $\left(\mathrm{d}^{-1}\right)$ in the mixed layer, $I_{\mathrm{m}}$, was estimated using the formula

$$
I_{\mathrm{mi}}=\frac{I_{0}}{K_{t} Z_{\mathrm{m}}}\left(1-\mathrm{e}^{-k_{t} Z_{\mathrm{m}}}\right)
$$

where $Z_{\mathrm{m}}$ is the depth of the mixed layer $(\mathrm{m})$, and $I_{0}$ is the mean daily surface PAR irradiance (Stefan et al. 1976). Florida Bay was assumed to be generally polymictic, hence $Z_{\mathrm{m}}$ was set equal to station depth. $I_{0}$ (mol photons $\mathrm{m}^{-2} \mathrm{~d}^{-1}$ of PAR) was obtained from literature values (Oswald \& Gataas 1957) and adjusted by month to account for seasonal variability in surface irradiance. Photic depth, $Z_{p}$, was estimated as $4.61 / K_{t}$ (Cloern 1987). 
Data analysis. Statistical analysis was performed using the SAS statistical program for personal computers (SAS 1989). Relationships between $K_{t}$ and other parameters were determined using Pearson correlation analyses.

\section{RESULTS}

\section{Spatial variation in light attenuation}

Mean light extinction coefficients, $K_{i}$, for the sampling period ranged from $0.66 \mathrm{~m}^{-1}$ at $\mathrm{Stn} 12$ to $2.82 \mathrm{~m}^{-1}$ at Stn 4 over the study period (Fig. 2B). Geographically the lowest light penetration was generally observed in the north-central and western regions of the bay. Greatest mean light penetration was found in the eastern and south-central regions of the bay.

Spatial variation in tripton, chl $a$, and color

Tripton concentrations were highest on the western side of the bay and lowest in the eastern regions (Fig. 3B). The estimated percentage contribution of tripton, $K_{\mathrm{s}}$, to total light attenuation, $K_{t}$, was highest in the eastern regions of the bay and lowest in the north-central region (Table 1).

The highest mean chl a concentrations for the study period were observed in the north-central region of the bay, while the lowest mean concentrations were found in the eastern side of the bay (Fig. 3A). The estimated contribution of phytoplankton. $K_{c}$, to $K_{1}$ followed the same spatial pattern as chlorophyll concentration (Table 1).

Color ranged from mean values less than 10 at Stns 7 to 17 , to means of 10 to 15 at Stns 1 to 6 (Fig 3C). The estimated contribution of color, $K_{\text {ac }}$ to $K_{t}$ was highest in the north-central region and lowest in the eastern regions of the bay (Table 1 ).
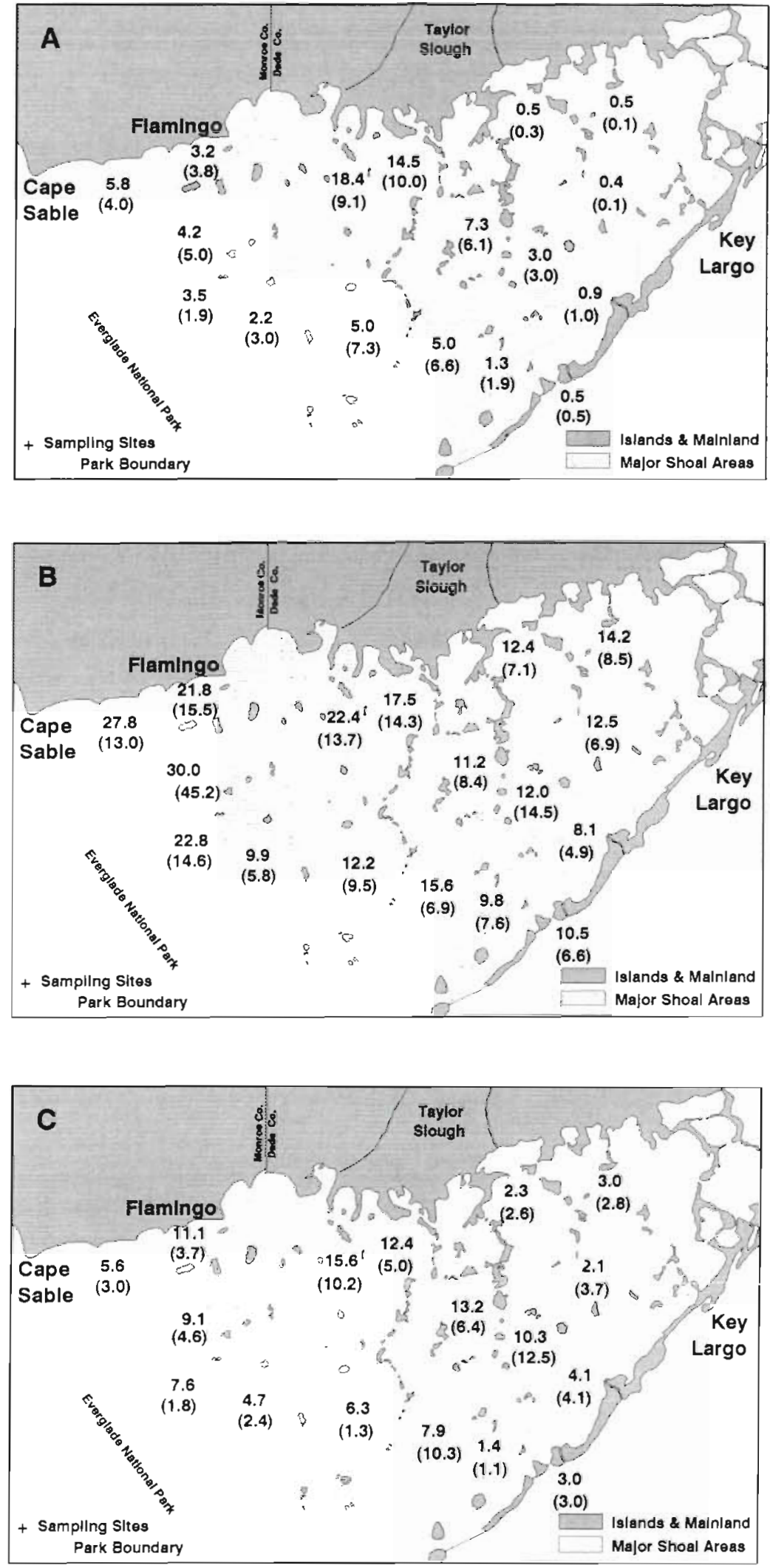

Fig. 3. (A) Mean chl a ( $\left.\mathrm{mg} \mathrm{m}^{-3}\right)$, (B) tripton $\left(\mathrm{g} \mathrm{m}^{-3}\right)$, and (C) color (pt units). Standard deviation in parentheses 
Table 1 Estimated percentage contribution of different components to total light attenuation. Partial coefficients include $K_{s}$ (tripton), $K_{\mathrm{c}}$ (chlorophyll-containing particles), $K_{\mathrm{ac}}$ (apparent color), and $K_{\mathrm{w}}$ (water). Standard deviation in parentheses

\begin{tabular}{|clccc|}
\hline Site & $K_{\mathrm{s}}$ & \multicolumn{1}{c}{$K_{\mathrm{c}}$} & $K_{\mathrm{dr}}$ & $K_{\text {, }}$ \\
\hline 1 & $69(25)$ & $14(10)$ & $13(19)$ & $4(1)$ \\
2 & $54(8)$ & $28(16)$ & $15(1))$ & $3(1)$ \\
3 & $54(17)$ & $31(17)$ & $13(7)$ & $2(1)$ \\
4 & $54(18)$ & $34(15)$ & $10(7)$ & $2(1)$ \\
5 & $79(7)$ & $11(6)$ & $8(4)$ & $2(1)$ \\
6 & $82(4)$ & $10(10)$ & $6(3)$ & $2(1)$ \\
7 & $72(11)$ & $14(14)$ & $9(5)$ & $5(1)$ \\
8 & $68(3)$ & $18(19)$ & $10(3)$ & $4(1)$ \\
9 & $82(25)$ & $10(16)$ & $3(2)$ & $5(1)$ \\
10 & $84(14)$ & $7(9)$ & $4(9)$ & $5(1)$ \\
11 & $78(9)$ & $16(8)$ & $3(2)$ & $3(1)$ \\
12 & $88(8)$ & $3(3)$ & $3(5)$ & $6(2)$ \\
13 & $90(10)$ & $2(1)$ & $3(9)$ & $5(2)$ \\
14 & $61(28)$ & $24(22)$ & $10(8)$ & $5(2)$ \\
15 & $92(3)$ & $3(2)$ & $3(4)$ & $4(1)$ \\
16 & $90(4)$ & $3(1)$ & $4(4)$ & $3(1)$ \\
17 & $75(6)$ & $14(8)$ & $8(3)$ & $3(1)$ \\
& & & & \\
\hline
\end{tabular}

\section{Correlation between $K_{t}$, tripton, chl $a$, and color}

The major variables related to light attenuation included in this study were chl a (an estimator of living phytoplankton in the water column), tripton (non-algal suspended solids), and color. For the pooled data set of all samples $K_{t}$ was most strongly correlated to tripton, followed by chl a (Table 2). $K_{t}$ was not significantly correlated to color for the overall data set, which was not surprising considering the generally low color values observed in the bay.

There were regional differences in the relative correlation of $K_{t}$ to tripton, chl a and color (Table 2). These regional differences can be split into 4 distinct geographical areas (Fig. 4). In the north-central region of the bay (Stns 2, $3 \& 4$ ) $K_{t}$ was most strongly correlated to chl a concentration, but also significantly correlated to tripton. In the southcentral region (Stns 7, $8 \& 14$ ) $K_{t}$ was strongly correlated to chl $a$ and weakly correlated to color, but not correlated to tripton. In the western region (Stns 5, 6, $11 \& 17$ ) $K_{t}$ was more strongly correlated to tripton than chl $a$. In the eastern region (Stns 1, 9, 10, 13, $15 \&$ 16) $K_{\ell}$ was significantly correlated to both chl a and tripton, but the Pearson Correlation Coefficients were relatively low.
Table 2. Pearson correlation coefficients for the relationship between light extinction coefficient, $K_{t}$, and 3 major components of light absorption: chl $a$, tripton and color. Correlations are compared for 4 distinct regions of Florida Bay. Probabilities in parentheses

\begin{tabular}{|c|c|c|c|}
\hline \multirow{2}{*}{ Region } & \multicolumn{3}{|c|}{$-K_{t} \times$} \\
\hline & Chl a & Tripton & Color \\
\hline North-central & $\begin{array}{c}0.824 \\
(<0.0001)\end{array}$ & $\begin{array}{l}0.698 \\
(0.0004)\end{array}$ & $\begin{array}{c}0.016 \\
(0.9463)\end{array}$ \\
\hline South-central & $\begin{array}{c}0.908 \\
(<0.0001)\end{array}$ & $\begin{array}{c}0.192 \\
(0.4321)\end{array}$ & $\begin{array}{c}0.500 \\
(0.0300)\end{array}$ \\
\hline East & $\begin{array}{c}0.455 \\
(0.0003)\end{array}$ & $\begin{array}{c}0.356 \\
(0.0389)\end{array}$ & $\begin{array}{c}0.141 \\
(0.4185)\end{array}$ \\
\hline West & $\begin{array}{c}0.620 \\
(<0.0001)\end{array}$ & $\begin{array}{c}0.844 \\
(<0.0001)\end{array}$ & $\begin{array}{c}0.082 \\
(0.7243)\end{array}$ \\
\hline Overall & $\begin{array}{c}0.731 \\
(<0.0001)\end{array}$ & $\begin{array}{c}0.754 \\
(<0.0001)\end{array}$ & $\begin{array}{c}0.254 \\
(0.0100)\end{array}$ \\
\hline
\end{tabular}

\section{Temporal variation in $K_{t}$ and chl a concentrations}

Regional differences were observed in temporal variation of $K_{t}$ and chl a concentrations over the study period (Fig. 5). In the north-central region, both $K_{1}$ and chl a showed considerable variability, but remained high throughout most of the year compared to other regions (Fig. 5A). In the southcentral region, peak $K_{t}$ and chl a concentrations occurred in fall (Fig. 5B). In the western region of

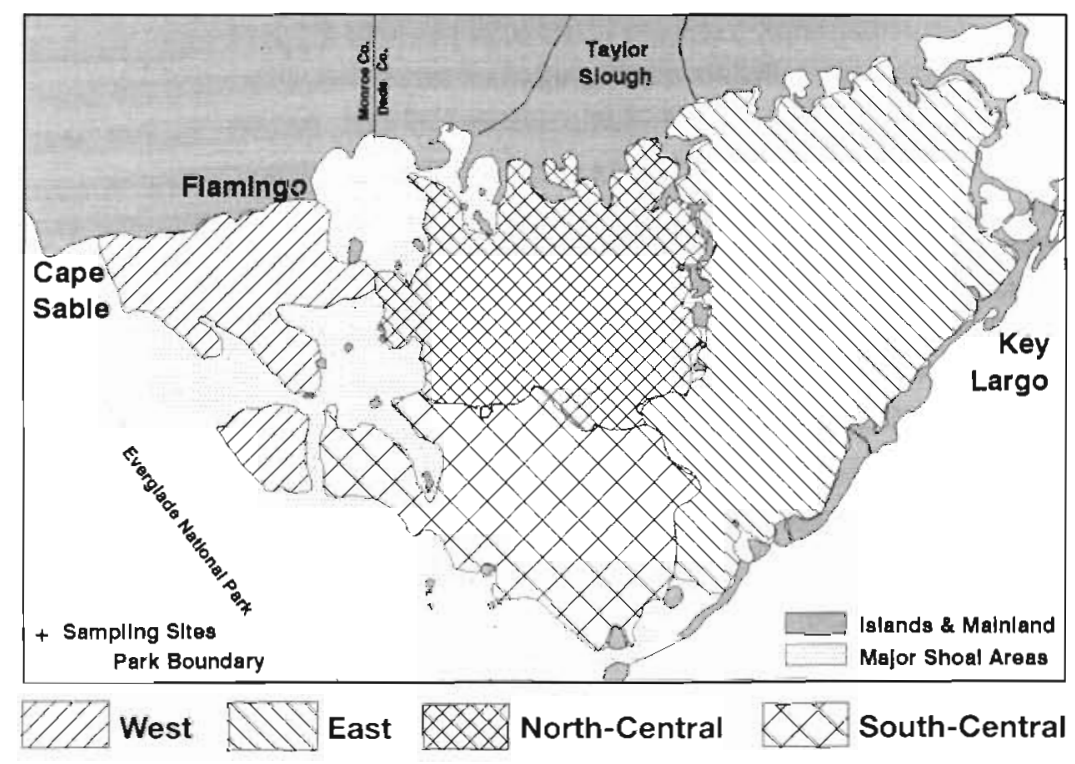

Fig. 4. Regions of Florida Bay with distinct relationships between $K_{t}$, tripton, chl $a$ and color 
the bay both $K_{t}$ and chl a showed multiple peaks in fall, spring and summer (Fig. 5C). In the eastern region $K_{t}$ and chl a concentrations were generally lower than in other regions of the bay (Fig. 5D). $K_{l}$ values were generally highest in spring, while chl a concentrations were highest in summer in the latter region.

\section{Estimates of pelagic and benthic light availability}

Mean daily light availability in the mixed layer, $I_{m}$ was generally lowest in the northwestern region of the bay and highest in the eastern region (Table 3 ). Another measure of light availability in the water column determined in this study was the ratio between photic depth, $Z_{\mathrm{p}}$, and mixing depth, $Z_{\mathrm{m}}$. This ratio followed the same general spatial and temporal pattern as $I_{\mathrm{m}}$ (Table 3). Benthic light availability, presented as percentage of surface irradiance, was lowest in the western and north-central regions of the bay and highest in the eastern and south-central regions (Table 4).
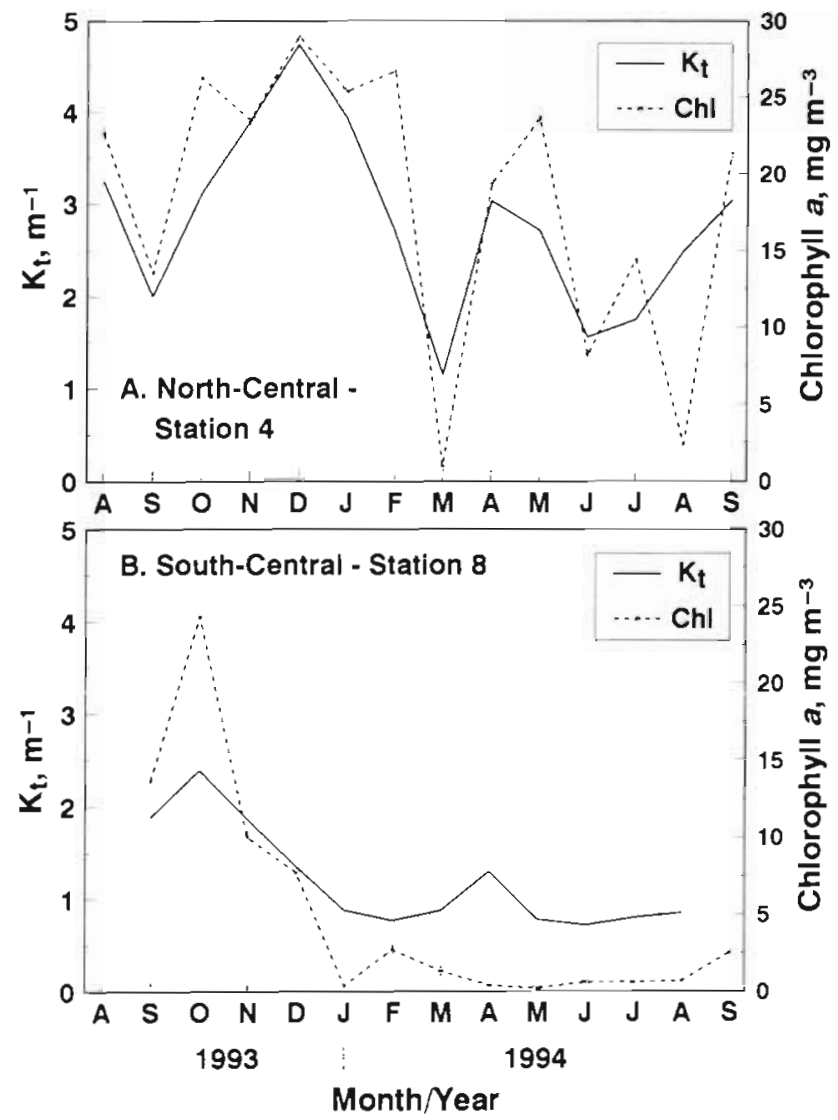

\section{DISCUSSION}

\section{Spatial and temporal variation in the character of light attenuation}

The properties and extent of light attenuation in Florida Bay vary between the water basins which comprise the $1500 \mathrm{~km}^{2}$ of this estuary. As in many shallow polymictic aquatic ecosystems, light extinction in Florida Bay is impacted by resuspension of bottom sediments. This impact is reflected in the correlations observed between $K_{t}$ and tripton (Table 2), as well as the high relative contribution of tripton to total light attenuation (Table 1). There are, however, noteworthy regional (Figure 4) disparities in the relative roles of tripton, color and phytoplankton in light attenuation.

In the north-central region of Florida Bay, high concentrations of chl a indicate a major role for phytoplankton in light attenuation. This is corroborated by the strong correlations between $K_{t}$ and chl $a$ in this region of the bay (Table 2 ), and by the substantial contribution of $K_{c}$ to $K_{t}$. The high chlorophyll levels observed during this study, up to $40 \mathrm{mg} \mathrm{m}^{-3}$, are in a
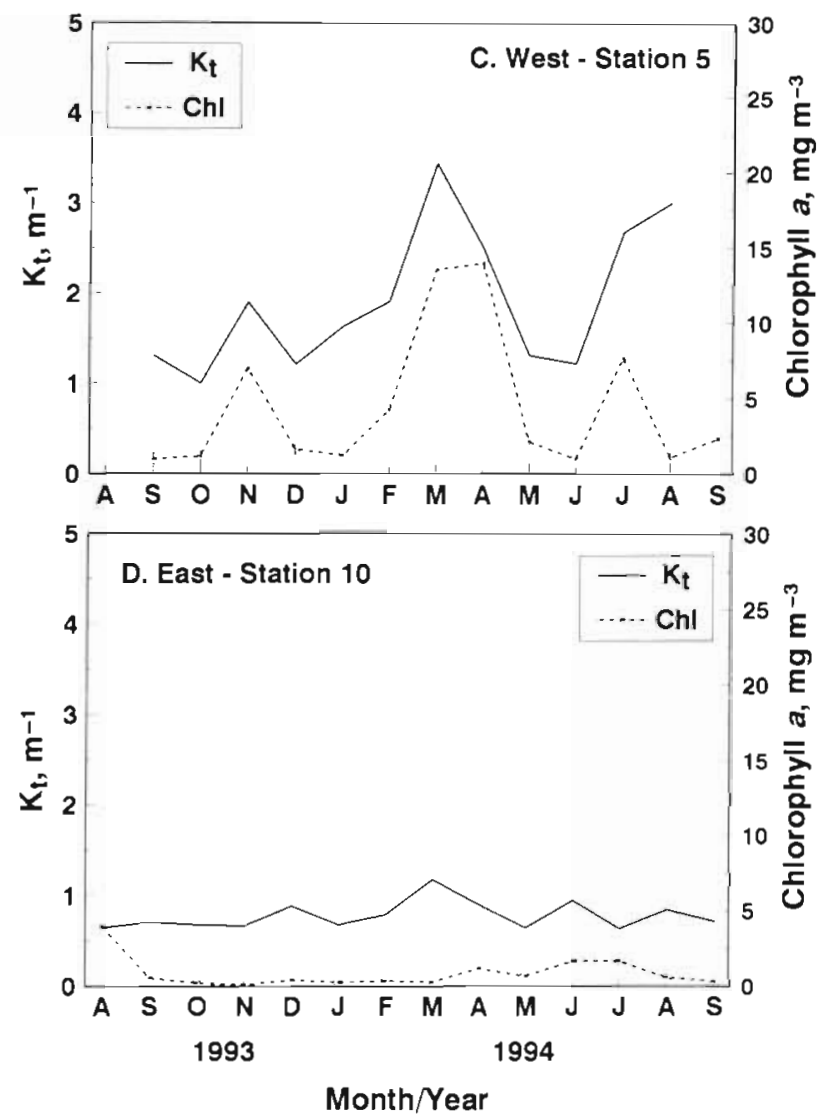

Fig. 5. Monthly $K_{i}$ and $c h l$ a values at 4 sampling sites representative of 4 distinct regions of Florida Bay 
Table 3. Ratio of photic depth, $Z_{p}$, to mixing depth, $Z_{m}$ (top value), and the mean irradiance in the mixed layer, $l_{m}$ ( $\mu$ mol photons $\mathrm{m}^{-2} \mathrm{~d}^{-1}$, bottom value), at 17 stations in Florida Bay. Bold type indicates that values are within the range of potential light limitation as defined in text

\begin{tabular}{|c|c|c|c|c|c|c|c|c|c|c|c|c|c|c|}
\hline \multirow[t]{2}{*}{ Site } & \multicolumn{14}{|c|}{ Sampling date } \\
\hline & $\begin{array}{l}\text { Aug } \\
1993\end{array}$ & $\begin{array}{l}\text { Sep } \\
1993\end{array}$ & $\begin{array}{c}\text { Oct } \\
1993\end{array}$ & $\begin{array}{l}\text { Nov } \\
1993\end{array}$ & $\begin{array}{c}\text { Dec } \\
1993\end{array}$ & $\begin{array}{c}\text { Jan } \\
1994\end{array}$ & $\begin{array}{l}\text { Feb } \\
1994\end{array}$ & $\begin{array}{l}\text { Mar } \\
1994\end{array}$ & $\begin{array}{c}\text { Apr } \\
1994\end{array}$ & $\begin{array}{l}\text { May } \\
1994\end{array}$ & $\begin{array}{c}\text { Jun } \\
1994\end{array}$ & $\begin{array}{c}\text { Jul } \\
1994\end{array}$ & $\begin{array}{l}\text { Aug } \\
1994\end{array}$ & $\begin{array}{c}\text { Sep } \\
1994\end{array}$ \\
\hline 1 & $\begin{array}{l}2.7 \\
12\end{array}$ & $\begin{array}{l}2.1 \\
8.9\end{array}$ & $\begin{array}{c}3.4 \\
10\end{array}$ & $\begin{array}{l}3.2 \\
8.1\end{array}$ & $\begin{array}{l}1.8 \\
5.0\end{array}$ & $\begin{array}{l}2.0 \\
5.6\end{array}$ & $\begin{array}{l}2.2 \\
7.4\end{array}$ & $\begin{array}{l}1.6 \\
6.9\end{array}$ & $\begin{array}{l}0.9 \\
4.8\end{array}$ & $\begin{array}{c}2.2 \\
11\end{array}$ & $\begin{array}{l}2.2 \\
11\end{array}$ & $\begin{array}{l}2.7 \\
13\end{array}$ & - & $\begin{array}{l}2.7 \\
11\end{array}$ \\
\hline 2 & $\begin{array}{l}1.2 \\
6.1\end{array}$ & $\begin{array}{l}\mathbf{1 . 1} \\
5.2\end{array}$ & $\begin{array}{l}2.2 \\
7.8\end{array}$ & $\begin{array}{l}2.0 \\
6.0\end{array}$ & $\begin{array}{l}1.6 \\
4.6\end{array}$ & $\begin{array}{l}1.5 \\
4.4\end{array}$ & $\begin{array}{l}1.8 \\
6.3\end{array}$ & $\begin{array}{l}\mathbf{1 . 3} \\
5.9\end{array}$ & $\begin{array}{l}1.1 \\
5.8\end{array}$ & $\begin{array}{c}2.4 \\
12\end{array}$ & $\begin{array}{c}2.2 \\
11\end{array}$ & $\begin{array}{c}2.6 \\
12\end{array}$ & $\begin{array}{l}3.0 \\
13\end{array}$ & $\begin{array}{l}3.2 \\
12\end{array}$ \\
\hline 3 & $\begin{array}{l}0.7 \\
3.8\end{array}$ & $\begin{array}{l}1.1 \\
5.4\end{array}$ & $\begin{array}{l}1.0 \\
4.1\end{array}$ & $\begin{array}{l}0.9 \\
2.8\end{array}$ & $\begin{array}{l}1.6 \\
4.5\end{array}$ & $\begin{array}{l}1.4 \\
4.3\end{array}$ & $\begin{array}{l}1.8 \\
6.3\end{array}$ & $\begin{array}{l}1.2 \\
5.3\end{array}$ & $\begin{array}{l}1.0 \\
5.0\end{array}$ & $\begin{array}{c}2.9 \\
13\end{array}$ & $\begin{array}{c}2.7 \\
13\end{array}$ & $\begin{array}{l}3.7 \\
15\end{array}$ & $\begin{array}{l}2.9 \\
13\end{array}$ & $\begin{array}{l}3.3 \\
12\end{array}$ \\
\hline 4 & $\begin{array}{l}1.4 \\
7.1\end{array}$ & $\begin{array}{c}2.6 \\
10\end{array}$ & $\begin{array}{l}1.5 \\
5.8\end{array}$ & $\begin{array}{l}1.1 \\
3.7\end{array}$ & $\begin{array}{l}1.1 \\
3.2\end{array}$ & $\begin{array}{l}1.7 \\
4.9\end{array}$ & $\begin{array}{l}1.9 \\
6.6\end{array}$ & $\begin{array}{l}5.0 \\
14\end{array}$ & $\begin{array}{l}1.7 \\
8.3\end{array}$ & $\begin{array}{l}1.9 \\
10\end{array}$ & $\begin{array}{l}3.3 \\
14\end{array}$ & $\begin{array}{c}2.6 \\
12\end{array}$ & $\begin{array}{l}1.7 \\
8.5\end{array}$ & $\begin{array}{l}1.5 \\
6.9\end{array}$ \\
\hline 5 & - & $\begin{array}{l}1.6 \\
7.2\end{array}$ & $\begin{array}{l}1.5 \\
6.0\end{array}$ & $\begin{array}{l}1.5 \\
4.8\end{array}$ & $\begin{array}{l}1.8 \\
4.9\end{array}$ & $\begin{array}{l}1.6 \\
4.6\end{array}$ & $\begin{array}{l}1.2 \\
4.5\end{array}$ & $\begin{array}{l}0.6 \\
2.8\end{array}$ & - & $\begin{array}{l}1.9 \\
10\end{array}$ & $\begin{array}{l}1.8 \\
10\end{array}$ & $\begin{array}{l}0.8 \\
4.2\end{array}$ & $\begin{array}{l}0.5 \\
2.8\end{array}$ & - \\
\hline 6 & - & $\begin{array}{l}1.5 \\
6.3\end{array}$ & $\begin{array}{l}2.8 \\
9.2\end{array}$ & $\begin{array}{l}1.4 \\
4.3\end{array}$ & $\begin{array}{l}3.4 \\
7.5\end{array}$ & $\begin{array}{l}4.0 \\
8.5\end{array}$ & $\begin{array}{l}3.0 \\
9.1\end{array}$ & $\begin{array}{l}2.3 \\
9.1\end{array}$ & $\begin{array}{l}0.7 \\
3.8\end{array}$ & $\begin{array}{l}2.9 \\
13\end{array}$ & $\begin{array}{l}2.9 \\
13\end{array}$ & $\begin{array}{l}2.4 \\
12\end{array}$ & $\begin{array}{c}2.2 \\
11\end{array}$ & - \\
\hline 7 & - & $\begin{array}{l}3.6 \\
12\end{array}$ & $\begin{array}{l}1.7 \\
6.4\end{array}$ & $\begin{array}{l}3.9 \\
9.0\end{array}$ & $\begin{array}{l}2.3 \\
5.9\end{array}$ & $\begin{array}{l}3.6 \\
8.1\end{array}$ & $\begin{array}{l}3.6 \\
10\end{array}$ & $\begin{array}{l}2.5 \\
9.7\end{array}$ & $\begin{array}{l}3.0 \\
13\end{array}$ & $\begin{array}{l}3.1 \\
14\end{array}$ & $\begin{array}{l}3.7 \\
15\end{array}$ & $\begin{array}{l}2.8 \\
13\end{array}$ & $\begin{array}{l}3.0 \\
13\end{array}$ & - \\
\hline 8 & - & $\begin{array}{l}0.9 \\
4.3\end{array}$ & $\begin{array}{l}0.9 \\
3.7\end{array}$ & $\begin{array}{l}1.1 \\
3.4\end{array}$ & $\begin{array}{l}1.5 \\
4.2\end{array}$ & $\begin{array}{l}2.6 \\
6.6\end{array}$ & $\begin{array}{l}2.9 \\
8.7\end{array}$ & $\begin{array}{l}2.4 \\
9.3\end{array}$ & $\begin{array}{l}1.7 \\
8.4\end{array}$ & $\begin{array}{c}2.6 \\
12\end{array}$ & $\begin{array}{l}2.9 \\
14\end{array}$ & $\begin{array}{l}2.6 \\
12\end{array}$ & $\begin{array}{l}2.4 \\
11\end{array}$ & - \\
\hline 9 & - & $\begin{array}{l}3.0 \\
11\end{array}$ & $\begin{array}{l}3.2 \\
10\end{array}$ & $\begin{array}{l}3.1 \\
7.9\end{array}$ & $\begin{array}{l}2.6 \\
6.5\end{array}$ & $\begin{array}{l}2.5 \\
6.5\end{array}$ & $\begin{array}{l}3.7 \\
10\end{array}$ & $\begin{array}{l}1.6 \\
6.8\end{array}$ & $\begin{array}{l}3.0 \\
12\end{array}$ & $\begin{array}{l}3.7 \\
15\end{array}$ & $\begin{array}{l}3.5 \\
15\end{array}$ & $\begin{array}{l}3.6 \\
15\end{array}$ & $\begin{array}{l}3.2 \\
13\end{array}$ & - \\
\hline 10 & $\begin{array}{l}2.7 \\
12\end{array}$ & $\begin{array}{l}2.7 \\
11\end{array}$ & $\begin{array}{l}3.4 \\
10\end{array}$ & $\begin{array}{l}3.1 \\
8.0\end{array}$ & $\begin{array}{l}2.3 \\
5.8\end{array}$ & $\begin{array}{l}2.9 \\
7.1\end{array}$ & $\begin{array}{l}2.4 \\
7.9\end{array}$ & $\begin{array}{l}1.6 \\
7.0\end{array}$ & $\begin{array}{l}2.3 \\
11\end{array}$ & $\begin{array}{l}3.1 \\
14\end{array}$ & $\begin{array}{l}2.0 \\
11\end{array}$ & $\begin{array}{l}3.1 \\
14\end{array}$ & $\begin{array}{l}2.2 \\
10\end{array}$ & $\begin{array}{l}2.5 \\
10\end{array}$ \\
\hline 11 & - & - & $\begin{array}{l}- \\
-\end{array}$ & $\begin{array}{l}0.5 \\
1.8\end{array}$ & $\begin{array}{l}1.2 \\
3.4\end{array}$ & $\begin{array}{l}0.5 \\
1.4\end{array}$ & $\begin{array}{l}0.5 \\
2.1\end{array}$ & $\begin{array}{l}0.3 \\
1.3\end{array}$ & $\begin{array}{l}0.5 \\
3.9\end{array}$ & $\begin{array}{l}0.5 \\
2.8\end{array}$ & $\begin{array}{l}1.3 \\
3.8\end{array}$ & $\begin{array}{l}0.5 \\
2.8\end{array}$ & $\begin{array}{l}0.4 \\
2.7\end{array}$ & - \\
\hline 12 & - & - & - & $\begin{array}{l}3.6 \\
7.3\end{array}$ & $\begin{array}{l}1.8 \\
5.0\end{array}$ & $\begin{array}{l}2.4 \\
7.0\end{array}$ & $\begin{array}{l}3.0 \\
8.9\end{array}$ & $\begin{array}{l}1.5 \\
5.0\end{array}$ & $\begin{array}{l}2.1 \\
12\end{array}$ & $\begin{array}{l}3.5 \\
15\end{array}$ & $\begin{array}{l}3.1 \\
14\end{array}$ & $\begin{array}{l}3.1 \\
13\end{array}$ & $\begin{array}{l}3.4 \\
14\end{array}$ & - \\
\hline 13 & - & $\begin{array}{l}- \\
-\end{array}$ & $\begin{array}{l}- \\
-\end{array}$ & - & $\begin{array}{l}1.5 \\
4.2\end{array}$ & $\begin{array}{l}0.9 \\
2.9\end{array}$ & $\begin{array}{l}2.1 \\
7.2\end{array}$ & $\begin{array}{l}1.7 \\
7.4\end{array}$ & $\begin{array}{l}4.0 \\
14\end{array}$ & $\begin{array}{c}2.5 \\
12\end{array}$ & $\begin{array}{l}3.2 \\
14\end{array}$ & $\begin{array}{l}4.1 \\
16\end{array}$ & $\begin{array}{l}2.8 \\
12\end{array}$ & $\begin{array}{l}3.3 \\
12\end{array}$ \\
\hline 14 & - & $\begin{array}{l}- \\
-\end{array}$ & - & - & $\begin{array}{l}- \\
-\end{array}$ & $\begin{array}{l}- \\
-\end{array}$ & $\begin{array}{l}- \\
-\end{array}$ & $\begin{array}{l}1.1 \\
5.0\end{array}$ & $\begin{array}{l}1.5 \\
7.6\end{array}$ & $\begin{array}{c}2.2 \\
11\end{array}$ & $\begin{array}{l}3.6 \\
15\end{array}$ & $\begin{array}{l}3.4 \\
14\end{array}$ & $\begin{array}{c}2.3 \\
11\end{array}$ & - \\
\hline 15 & $\begin{array}{l}- \\
-\end{array}$ & - & $\begin{array}{l}- \\
-\end{array}$ & - & $\begin{array}{l}- \\
-\end{array}$ & - & - & - & - & $\begin{array}{l}3.2 \\
14\end{array}$ & $\begin{array}{l}3.1 \\
14\end{array}$ & $\begin{array}{l}2.5 \\
12\end{array}$ & $\begin{array}{l}3.7 \\
14\end{array}$ & $\begin{array}{l}3.7 \\
13\end{array}$ \\
\hline 16 & $\begin{array}{l}- \\
-\end{array}$ & - & $\begin{array}{l}- \\
-\end{array}$ & - & - & - & - & - & $\begin{array}{l}- \\
-\end{array}$ & $\begin{array}{l}3.6 \\
15\end{array}$ & $\begin{array}{l}4.2 \\
16\end{array}$ & $\begin{array}{l}3.7 \\
15\end{array}$ & $\begin{array}{l}3.0 \\
13\end{array}$ & - \\
\hline 17 & - & - & - & - & - & $\begin{array}{l}- \\
-\end{array}$ & - & - & $\begin{array}{l}- \\
-\end{array}$ & $\begin{array}{l}1.6 \\
8.4\end{array}$ & $\begin{array}{c}2.3 \\
11\end{array}$ & $\begin{array}{l}1.5 \\
7.8\end{array}$ & $\begin{array}{l}1.8 \\
9.0\end{array}$ & - \\
\hline
\end{tabular}

similar range to those reported for several eutrophic tropical lagoons, including the Lagoa de Guarapina in Brazil (Knoppers et al. 1991), Laguna de Términos in Mexico (Day et al. 1988), Ebrie Lagoon on the Ivory Coast (Dufour \& Slephoukha 1981) and the PeelHarvey Estuary in Australia (Hodgkin \& Birch 1986). One of the major features shared by this region of Florida Bay and the latter ecosystems is low turnover rates of water. However, the high biovolumes (up to

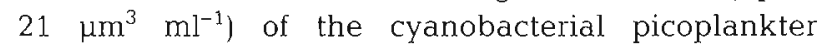
Synechococcus sp. observed in this region through the entire year of sampling (Phlips \& Badylak 1995) contrast with the latter ecosystems, which are more commonly characterized by an annual succession of dinoflagellate, diatom and cyanobacteria dominated populations and in some cases benthic macroalgae
(Hodgkin \& Birch 1986). This may in part be due to the hypersaline conditions which have become a common feature of this region (Boesch et al. 1993), and may favor this euryhaline cyanobacterium (Phlips et al. 1989, Phlips \& Badylak 1995).

Despite the high phytoplankton concentrations observed in the north-central region of Florida Bay, tripton remains the major component of light attenuation because of the shallow polymictic water column and flocculent muddy sediments. Color also contributes substantially to light attenuation, although not nearly to the extent observed in estuaries subject to major inflows from organically stained rivers (Kirk 1980, Grandberg \& Harjula 1982, Arvola 1984, McPherson \& Miller 1987). The higher color values in this region of the bay compared to other areas may be 
Table 4. Percentage of surface irradiance available at the sediment surface at 17 sampling stations in Florida Bay. Values are mean values for 4 seasons of 1 yr of the sampling period: fall: September, October and November; winter: December, January and February; spring: March, April and May; summer: June, July and August

\begin{tabular}{|rrrrr|}
\hline Site & Fall & $\begin{array}{c}\text { Winter } \\
1993-94\end{array}$ & $\begin{array}{c}\text { Spring } \\
1994\end{array}$ & $\begin{array}{c}\text { Summer } \\
1994\end{array}$ \\
\hline 1 & 1993 & 10 & 6 & 15 \\
2 & 20 & 6 & 7 & 17 \\
3 & 8 & 6 & 8 & 22 \\
4 & 1 & 5 & 18 & 16 \\
5 & 8 & 5 & 4 & 3 \\
6 & 5 & 26 & 11 & 15 \\
7 & 9 & 23 & 20 & 23 \\
8 & 22 & 14 & 13 & 17 \\
9 & 1 & 21 & 18 & 26 \\
10 & 22 & 16 & 14 & 15 \\
11 & 22 & 1 & 0 & 1 \\
12 & 0 & 15 & 14 & 24 \\
13 & - & 5 & 18 & 25 \\
14 & - & - & 6 & 22 \\
15 & - & - & 24 & 22 \\
16 & - & - & 28 & 28 \\
17 & - & - & 5 & 8 \\
& & - & & \\
\hline
\end{tabular}

attributable to water inflows from tidal creeks in the Everglades and from decomposition of senescent seagrasses. The die-off and decomposition of seagrasses provides additional internal sources of nutrients for the further proliferation of phytoplankton blooms (Boesch et al. 1993, Armentano et al. 1994).

The south-central region of Florida Bay is characterized by a series of water basins with predominantly low water column chl a and tripton concentrations and low $K_{t}$. This pattern is periodically interrupted by elevated chl a and $K_{t}$ values (Fig. 5B), forming the basis for significant relationships between $K$, and chl a (Table 2). The firm sediments and regionally abundant seagrass communities in these basins result in comparatively low tripton levels, as manifested by the poor correlation between $K_{1}$ and tripton. The role of seagrass communities in reducing sediment resuspension has been reported for other estuarine ecosystems (Ward et al. 1984). The south-central water basins of Florida Bay are also partially isolated from the influence of tidal mixing due to the presence of surrounding islands and shoals (Fig. 1), that further contribute to lowered tripton levels. The periodic appearance of algal blooms in these regions may be a consequence of episodic influxes of water from the north-central region of the bay caused by wind and tidally driven southward flow of water, particularly during periods of freshwater inflow from Taylor Slough in the Everglades (Fig. 1).
The western region of Florida Bay is characterized by strong tidal water exchange with the Gulf of Mexico. The high $K_{t}$ values observed in this region are a combined result of high tripton levels and periodically elevated phytoplankton concentrations, resulting in correlations of $K_{t}$ to both chl a and tripton concentrations (Table 2). It is probable that tidal inflows from the Gulf of Mexico play a major role in exogenous inputs of algae, nutrients and suspended solids to this region of the bay. Recent studies of phytoplankton in western Florida Bay reveal considerable temporal variability of community structure distinct from that observed in other regions of the bay (Phlips \& Badylak 1995), reflecting the influence of tidal water exchange with the Gulf of Mexico. In addition, tidal energy is a potentially major factor in vertical mixing of the water column and sediment resuspension. Tidally induced mixing has been shown to directly influence the dynamics of phytoplankton populations in estuarine environments by enhancing the potential for light limitation of photosynthesis (Cloern 1987). Cloern (1987) demonstrated that phytoplankton standing crop is inversely proportional to tidal mixing in the south San Francisco Bay estuary because of increased vertical stratification of the water column at low eddy diffusivity. The fact that Florida Bay is considerably shallower than south San Francisco Bay indicates that vertical stratification is unlikely to be a major consideration in light limitation in the former system.

In the eastern region of Florida Bay, low concentrations of both algal (i.e. $<2 \mathrm{mg} \mathrm{m}^{-3} \mathrm{chl}$ a concentrations) and non-algal suspended solids (tripton), as well as negligible water color, result in only weak correlations between $K_{l}$ values and the former 2 variables (Table 2 ). Light attenuation can be influenced by wind resuspension of the sand and calcium carbonate sediments characteristic of this region of the bay. This yields higher $K_{t}$ values during the winter/spring windy season (Fig. 5D). During periods of high winds the water column in these areas can take on a milky-white appearance due to resuspended tripton.

\section{Light availability for phytoplankton production}

Regional differences in the nature and extent of light attenuation potentially affect light availability for both planktonic and benthic primary production. Despite the generally shallow and polymictic character of Florida Bay, the potential for light limitation of phytoplankton production cannot be ruled out, particularly in regions of the bay subject to high tripton levels. Recent studies of several major estuaries have identified tripton loading from rivers and/or sediment resuspension as the cause of light limitation for phytoplankton production. 
These include the Bristol Channel, UK (Joint \& Pomroy 1981), Delaware Bay, USA (Pennock \& Sharp 1986), Ems-Dollard, The Netherlands (Colijn 1983), Hudson River, USA (Malone 1977), San Francisco Bay, USA (Cloern 1987), upper Chesapeake Bay, USA (Harding et al. 1986) and Wadden Sea, The Netherlands (Cadee \& Hegeman 1979) estuaries. In a comparative study of light limitation in these estuaries, Cloern (1987) showed that net water column production decreases rapidly when $Z_{\mathrm{p}}: Z_{\mathrm{m}}$ (i.e. the ratio of photic depth and mixing depth) drops below 1.5, and 'it approaches zero as $Z_{\mathrm{p}}: Z_{\mathrm{m}}$ approaches a critical ratio between 0.1 and 0.5 (depending on respiration)'. $Z_{\mathrm{p}}: Z_{\mathrm{m}}$ values less than 1.5 were observed at several sampling sites in Florida Bay (Table 3), particularly in the north-central and northwestern regions of the bay (Fig. 4), but seldom reached the 'critical range' of 0.1 to 0.5 , except at Stn 11, a relatively deep (ca $3 \mathrm{~m}$ ) and tripton-rich sampling site.

Researchers in shallow polymictic lake ecosystems have used another measure of light availability, mean irradiance in the mixed layer, $I_{m}$, to establish light limitation of phytoplankton production and standing crops (Walmsley 1978, Ganf 1980, Oliver 1981, Geddes 1984, Limon et al. 1989, Phlips et al. 1993, 1995a, b). Estimates of the threshold level of daily $I_{\mathrm{m}}$ for the onset of light limitation range from 2 to $5 \mathrm{~mol}$ photons $\mathrm{m}^{-2} \mathrm{~d}^{-1}$ (Oliver 1981, Geddes 1984, Phlips et al. 1995b). As in the case of estuarine systems, tripton plays a major role in producing light-limiting conditions for phytoplankton production in lakes, as highlighted in studies of shallow polymictic Lake Chapala, Mexico (Limon et al. 1989) and Lake Okeechobee, Florida (Phlips et al. 1995a, b). $I_{\mathrm{m}}$ values observed at certain sampling sites in Florida Bay periodically fell within, or near, this threshold range (Table 3), particularly in the western region characterized by high tripton concentrations. $I_{\mathrm{m}}$ values were typically lower during the windy season, late fall to early spring, as expected from the enhanced wave-induced resuspension of sediments.

The spatial and temporal patterns of both $I_{\mathrm{m}}$ and $Z_{\mathrm{p}}: Z_{\mathrm{m}}$ values in Florida Bay indicate the greatest potential for light limitation of phytoplankton production in the deeper areas of the western region of the bay, during the windy season. It is clear that the uniformly shallow depth of Florida Bay diminishes the overall potential magnitude of light limitation, despite the presence of high tripton concentrations in many regions of the bay.

\section{Light availability for benthic primary production}

In terms of benthic primary production, recent observations of extensive die-offs of seagrasses in Florida Bay have led to a number of alternative hypotheses concerning the causal factors involved (Robblee et al. 1991, Boesch et al. 1993), including the possible role of light limitation. The importance of light availability in controlling the maximum depth of seagrass colonization in other aquatic ecosystems is well established (Dennison 1987, Dawes \& Tomasko 1988, Duarte 1991). Several different model relationships between light attenuation and depth maxima for seagrass colonization, $D_{m}$, have been presented in the literature (Vincente \& Rivera 1982, Dennison 1987, Nielsen et al. 1989, Duarte 1991), ranging from $D_{\mathrm{m}}=1.36 / K_{t}$ (Vincente \& Rivera 1982) to $D_{\mathrm{m}}=1.86 / K_{t}$ (Duarte 1991). Based on the regression relationships developed by Duarte (1991) light extinction coefficients in a number of regions within Florida Bay showed values high enough to theoretically preclude successful colonization by seagrasses (Table 5). At sampling sites in the northwestern region of the bay (Stns $5 \& 11$ ) station depth fell below the colonization depth, $D_{\mathrm{m}}$, during all sampling dates, indicating a clear potential for light limitation of seagrass biomass. These 2 sampling sites are characterized by sparse benthic vegetation.

In the north-central region of Florida Bay (Stns 1, 2 , $3 \& 4$ ), the potential for light limitation was greatest in fall, winter and spring (Table 5). Mass mortalities of seagrasses have been recently observed in this region of the bay (Robblee et al. 1991). The search for causes of these mortalities have focussed on salinity variations, but the question remains largely unresolved (Boesch et al. 1993). The high frequency of sampling dates in this study when station depth exceeded $D_{\mathrm{m}}$ indicate that light limitation warrants consideration in relation to these mortalities. The apparent recent proliferation of phytoplankton blooms in the north-central region of Florida Bay (Phlips \& Badylak 1995) may have contributed to the reduction of light availability for benthic plant production, as indicated by the substantial contribution of phytoplankton to total light attenuation.

Most of the eastern and south-central regions of Florida Bay exhibited a low potential for light limitation, i.e. Stns 6, 7, 9\& 10. However, in some basins within this region low light availability was observed for extended periods during the study, as a result of episodic increases in phytoplankton concentrations. At Stns 8 \& 14 station depths were significantly greater than $D_{\mathrm{m}}$ for 3 to 4 contiguous months of the sampling period.

Depth $/ D_{\mathrm{m}}$ relationships provide a useful tool in discussing the potential for light limitation of seagrass distribution in Florida Bay, and corroborate observations of recent mass mortalities of seagrasses in the bay. Even under more general guidelines for light limitation of seagrass colonization, i.e. $10 \%$ of incident irradiance (Kenworthy \& Haunert 1991, Morris \& To- 
Table 5. Critical depth for seagrass colonization (top value, in $\mathrm{m}$ ), and observed station depth (bottom value, in $\mathrm{m}$ ), at $17 \mathrm{sampling}$ sites in Florida Bay. Critical depths were estimated as $1.86 / K_{1}$ (Duarte 1991). Bold type indicates that observed depths were substantially greater than critical depth (i.e. $>0.2 \mathrm{~m}$ deeper)

\begin{tabular}{|c|c|c|c|c|c|c|c|c|c|c|c|c|c|c|}
\hline \multirow[t]{2}{*}{ Site } & \multicolumn{14}{|c|}{ Sampling date } \\
\hline & $\begin{array}{l}\text { Aug } \\
1993\end{array}$ & $\begin{array}{c}\text { Sep } \\
1993\end{array}$ & $\begin{array}{c}\text { Oct } \\
1993\end{array}$ & $\begin{array}{l}\text { Nov } \\
1993\end{array}$ & $\begin{array}{c}\text { Dec } \\
1993\end{array}$ & $\begin{array}{c}\text { Jan } \\
1994\end{array}$ & $\begin{array}{l}\text { Feb } \\
1994\end{array}$ & $\begin{array}{c}\text { Mar } \\
1994\end{array}$ & $\begin{array}{c}\text { Apr } \\
1994\end{array}$ & $\begin{array}{l}\text { May } \\
1994\end{array}$ & $\begin{array}{c}\text { Jun } \\
1994\end{array}$ & $\begin{array}{c}\text { Jul } \\
1994\end{array}$ & $\begin{array}{l}\text { Aug } \\
1994\end{array}$ & $\begin{array}{c}\text { Sep } \\
1994\end{array}$ \\
\hline 1 & $\begin{array}{l}2.4 \\
2.2\end{array}$ & $\begin{array}{l}1.7 \\
2.0\end{array}$ & $\begin{array}{l}2.2 \\
1.6\end{array}$ & $\begin{array}{l}2.3 \\
1.8\end{array}$ & $\begin{array}{l}1.5 \\
2.1\end{array}$ & $\begin{array}{l}1.4 \\
1.7\end{array}$ & $\begin{array}{l}1.5 \\
1.7\end{array}$ & $\begin{array}{l}1.2 \\
1.9\end{array}$ & $\begin{array}{l}0.7 \\
2.0\end{array}$ & $\begin{array}{l}1.9 \\
2.1\end{array}$ & $\begin{array}{l}2.1 \\
2.3\end{array}$ & $\begin{array}{l}2.3 \\
2.1\end{array}$ & - & $\begin{array}{l}2.7 \\
2.4\end{array}$ \\
\hline 2 & $\begin{array}{l}1.0 \\
2.1\end{array}$ & $\begin{array}{l}1.0 \\
2.1\end{array}$ & $\begin{array}{l}1.8 \\
2.0\end{array}$ & $\begin{array}{l}1.7 \\
2.1\end{array}$ & $\begin{array}{l}1.4 \\
2.1\end{array}$ & $\begin{array}{l}1.2 \\
2.0\end{array}$ & $\begin{array}{l}1.3 \\
1.9\end{array}$ & $\begin{array}{l}1.0 \\
1.9\end{array}$ & $\begin{array}{l}0.9 \\
2.1\end{array}$ & $\begin{array}{l}1.8 \\
1.8\end{array}$ & $\begin{array}{l}1.6 \\
1.8\end{array}$ & $\begin{array}{l}2.1 \\
2.0\end{array}$ & $\begin{array}{l}2.4 \\
2.0\end{array}$ & $\begin{array}{l}2.9 \\
2.2\end{array}$ \\
\hline 3 & $\begin{array}{l}0.5 \\
1.7\end{array}$ & $\begin{array}{l}0.8 \\
1.7\end{array}$ & $\begin{array}{l}0.8 \\
1.9\end{array}$ & $\begin{array}{l}0.6 \\
1.6\end{array}$ & $\begin{array}{l}0.9 \\
1.4\end{array}$ & $\begin{array}{l}0.8 \\
1.4\end{array}$ & $\begin{array}{l}1.0 \\
1.4\end{array}$ & $\begin{array}{l}0.8 \\
1.7\end{array}$ & $\begin{array}{l}0.5 \\
1.4\end{array}$ & $\begin{array}{l}1.6 \\
1.4\end{array}$ & $\begin{array}{l}1.6 \\
1.5\end{array}$ & $\begin{array}{l}2.1 \\
1.4\end{array}$ & $\begin{array}{l}1.8 \\
1.5\end{array}$ & $\begin{array}{l}2.1 \\
1.6\end{array}$ \\
\hline 4 & $\begin{array}{l}0.6 \\
\mathbf{1 . 0}\end{array}$ & $\begin{array}{l}0.9 \\
0.9\end{array}$ & $\begin{array}{l}0.6 \\
1.0\end{array}$ & $\begin{array}{l}0.5 \\
1.1\end{array}$ & $\begin{array}{l}0.4 \\
0.9\end{array}$ & $\begin{array}{l}0.5 \\
0.7\end{array}$ & $\begin{array}{l}0.7 \\
0.9\end{array}$ & $\begin{array}{l}1.6 \\
0.8\end{array}$ & $\begin{array}{l}0.6 \\
\mathbf{0 . 9}\end{array}$ & $\begin{array}{l}0.7 \\
0.9\end{array}$ & $\begin{array}{l}1.2 \\
0.9\end{array}$ & $\begin{array}{l}1.0 \\
1.0\end{array}$ & $\begin{array}{l}0.7 \\
1.1\end{array}$ & $\begin{array}{l}0.6 \\
\mathbf{1 . 0}\end{array}$ \\
\hline 5 & $\begin{array}{l}- \\
-\end{array}$ & $\begin{array}{l}1.4 \\
2.2\end{array}$ & $\begin{array}{l}1.9 \\
2.2\end{array}$ & $\begin{array}{l}1.0 \\
2.0\end{array}$ & $\begin{array}{l}1.5 \\
2.1\end{array}$ & $\begin{array}{l}1.1 \\
1.8\end{array}$ & $\begin{array}{l}1.0 \\
2.0\end{array}$ & $\begin{array}{l}0.5 \\
2.2\end{array}$ & $\begin{array}{l}- \\
-\end{array}$ & $\begin{array}{l}1.4 \\
1.9\end{array}$ & $\begin{array}{l}1.5 \\
1.9\end{array}$ & $\begin{array}{l}0.7 \\
2.3\end{array}$ & $\begin{array}{l}0.6 \\
2.3\end{array}$ & - \\
\hline 6 & - & $\begin{array}{l}0.8 \\
1.4\end{array}$ & $\begin{array}{l}1.7 \\
1.5\end{array}$ & $\begin{array}{l}0.5 \\
\mathbf{0 . 9}\end{array}$ & $\begin{array}{l}1.6 \\
1.2\end{array}$ & $\begin{array}{l}1.3 \\
0.8\end{array}$ & $\begin{array}{l}1.4 \\
1.1\end{array}$ & $\begin{array}{l}1.3 \\
1.3\end{array}$ & $\begin{array}{l}0.3 \\
1.1\end{array}$ & $\begin{array}{l}1.4 \\
1.2\end{array}$ & $\begin{array}{l}1.3 \\
1.1\end{array}$ & $\begin{array}{l}1.3 \\
1.3\end{array}$ & $\begin{array}{l}1.1 \\
1.2\end{array}$ & - \\
\hline 7 & - & $\begin{array}{l}2.6 \\
1.8\end{array}$ & $\begin{array}{l}1.4 \\
2.1\end{array}$ & $\begin{array}{l}2.8 \\
1.8\end{array}$ & $\begin{array}{l}2.0 \\
2.1\end{array}$ & $\begin{array}{l}2.6 \\
1.8\end{array}$ & $\begin{array}{l}2.9 \\
2.0\end{array}$ & $\begin{array}{l}2.1 \\
2.2\end{array}$ & $\begin{array}{l}2.1 \\
1.7\end{array}$ & $\begin{array}{l}2.7 \\
2.2\end{array}$ & $\begin{array}{l}3.0 \\
2.0\end{array}$ & $\begin{array}{l}2.5 \\
2.2\end{array}$ & $\begin{array}{l}2.2 \\
1.8\end{array}$ & $\begin{array}{l}- \\
-\end{array}$ \\
\hline 8 & - & $\begin{array}{l}1.0 \\
2.7\end{array}$ & $\begin{array}{l}0.8 \\
2.1\end{array}$ & $\begin{array}{l}1.0 \\
2.4\end{array}$ & $\begin{array}{l}1.4 \\
2.3\end{array}$ & $\begin{array}{l}2.1 \\
2.0\end{array}$ & $\begin{array}{l}2.4 \\
2.1\end{array}$ & $\begin{array}{l}2.1 \\
2.2\end{array}$ & $\begin{array}{l}1.4 \\
2.1\end{array}$ & $\begin{array}{l}2.4 \\
2.3\end{array}$ & $\begin{array}{l}2.6 \\
2.2\end{array}$ & $\begin{array}{l}2.3 \\
2.2\end{array}$ & $\begin{array}{l}2.2 \\
2.3\end{array}$ & $\begin{array}{l}- \\
-\end{array}$ \\
\hline 9 & $\begin{array}{l}- \\
-\end{array}$ & $\begin{array}{l}2.3 \\
1.9\end{array}$ & $\begin{array}{l}1.9 \\
1.5\end{array}$ & $\begin{array}{l}2.4 \\
1.9\end{array}$ & $\begin{array}{l}1.9 \\
1.8\end{array}$ & $\begin{array}{l}1.7 \\
1.7\end{array}$ & $\begin{array}{l}2.5 \\
1.7\end{array}$ & $\begin{array}{l}1.1 \\
1.8\end{array}$ & $\begin{array}{l}2.3 \\
1.9\end{array}$ & $\begin{array}{l}2.7 \\
1.8\end{array}$ & $\begin{array}{l}2.7 \\
1.9\end{array}$ & $\begin{array}{l}2.7 \\
1.9\end{array}$ & $\begin{array}{l}2.7 \\
2.1\end{array}$ & - \\
\hline 10 & $\begin{array}{l}2.9 \\
2.6\end{array}$ & $\begin{array}{l}2.6 \\
2.4\end{array}$ & $\begin{array}{l}2.7 \\
2.0\end{array}$ & $\begin{array}{l}2.8 \\
2.2\end{array}$ & $\begin{array}{l}2.1 \\
2.3\end{array}$ & $\begin{array}{l}2.7 \\
2.4\end{array}$ & $\begin{array}{l}2.4 \\
2.4\end{array}$ & $\begin{array}{l}1.6 \\
2.4\end{array}$ & $\begin{array}{l}2.1 \\
2.2\end{array}$ & $\begin{array}{l}2.9 \\
2.3\end{array}$ & $\begin{array}{l}2.0 \\
2.4\end{array}$ & $\begin{array}{l}2.9 \\
2.3\end{array}$ & $\begin{array}{l}2.2 \\
2.5\end{array}$ & $\begin{array}{l}2.6 \\
2.6\end{array}$ \\
\hline 11 & $\begin{array}{l}- \\
-\end{array}$ & - & $\begin{array}{l}- \\
-\end{array}$ & $\begin{array}{l}0.9 \\
4.0\end{array}$ & $\begin{array}{l}1.9 \\
4.0\end{array}$ & $\begin{array}{l}0.7 \\
4.0\end{array}$ & $\begin{array}{l}0.9 \\
4.0\end{array}$ & $\begin{array}{l}0.4 \\
\mathbf{4 . 0}\end{array}$ & $\begin{array}{l}0.8 \\
3.6\end{array}$ & $\begin{array}{l}0.8 \\
4.0\end{array}$ & $\begin{array}{l}2.0 \\
3.8\end{array}$ & $\begin{array}{l}0.8 \\
4.0\end{array}$ & $\begin{array}{l}0.6 \\
3.8\end{array}$ & - \\
\hline 12 & - & $\begin{array}{l}- \\
-\end{array}$ & - & $\begin{array}{l}4.4 \\
3.0\end{array}$ & $\begin{array}{l}2.1 \\
2.8\end{array}$ & $\begin{array}{l}2.3 \\
2.5\end{array}$ & $\begin{array}{l}3.1 \\
2.6\end{array}$ & $\begin{array}{l}1.7 \\
\mathbf{3 . 0}\end{array}$ & $\begin{array}{l}2.2 \\
2.5\end{array}$ & $\begin{array}{l}4.1 \\
2.9\end{array}$ & $\begin{array}{l}4.0 \\
3.0\end{array}$ & $\begin{array}{l}3.6 \\
2.9\end{array}$ & $\begin{array}{l}3.6 \\
2.6\end{array}$ & $\begin{array}{l}- \\
-\end{array}$ \\
\hline 13 & - & - & - & - & $\begin{array}{l}1.4 \\
2.3\end{array}$ & $\begin{array}{l}0.8 \\
2.1\end{array}$ & $\begin{array}{l}1.7 \\
2.0\end{array}$ & $\begin{array}{l}1.5 \\
2.1\end{array}$ & $\begin{array}{l}3.1 \\
1.9\end{array}$ & $\begin{array}{l}2.1 \\
2.1\end{array}$ & $\begin{array}{l}2.6 \\
2.0\end{array}$ & $\begin{array}{l}3.3 \\
2.0\end{array}$ & $\begin{array}{l}2.5 \\
2.2\end{array}$ & $\begin{array}{l}3.0 \\
2.2\end{array}$ \\
\hline 14 & - & - & - & - & - & $\begin{array}{l}- \\
-\end{array}$ & - & $\begin{array}{l}1.1 \\
2.4\end{array}$ & $\begin{array}{l}1.3 \\
2.1\end{array}$ & $\begin{array}{l}2.2 \\
2.4\end{array}$ & $\begin{array}{l}3.4 \\
2.4\end{array}$ & $\begin{array}{l}3.2 \\
2.3\end{array}$ & $\begin{array}{l}2.5 \\
2.6\end{array}$ & - \\
\hline 15 & - & $\begin{array}{l}- \\
-\end{array}$ & - & - & - & $\begin{array}{l}- \\
-\end{array}$ & $\begin{array}{l}- \\
-\end{array}$ & - & - & $\begin{array}{l}2.1 \\
1.6\end{array}$ & $\begin{array}{l}2.1 \\
1.7\end{array}$ & $\begin{array}{l}2.0 \\
1.9\end{array}$ & $\begin{array}{l}2.7 \\
1.8\end{array}$ & $\begin{array}{l}2.9 \\
1.9\end{array}$ \\
\hline 16 & - & $\begin{array}{l}- \\
-\end{array}$ & - & - & - & $\begin{array}{l}- \\
-\end{array}$ & - & - & - & $\begin{array}{l}2.0 \\
1.4\end{array}$ & $\begin{array}{l}2.2 \\
1.3\end{array}$ & $\begin{array}{l}2.0 \\
1.4\end{array}$ & $\begin{array}{l}1.8 \\
1.4\end{array}$ & $\begin{array}{l}- \\
-\end{array}$ \\
\hline 17 & - & $\begin{array}{l}- \\
-\end{array}$ & - & - & - & - & - & - & - & $\begin{array}{l}1.3 \\
2.1\end{array}$ & $\begin{array}{l}1.6 \\
1.8\end{array}$ & $\begin{array}{l}1.3 \\
2.3\end{array}$ & $\begin{array}{l}1.3 \\
1.8\end{array}$ & - \\
\hline
\end{tabular}

masko 1993), there is a potential for light limitation of seagrass development in certain areas of Florida Bay, particularly during fall, winter and spring (Table 4).

Light attenuation by the water column is of course only one aspect of the issue of light limitation in seagrass communities. The degree of epiphytic colonization of seagrasses (Sand-Jensen 1977, Bulthuis \& Woelkerling 1983, Borum 1985, Libes 1986, Silberstein et al. 1986), as well as the overall physiological condition of the seagrass community (e.g. nutrient availability, ionic balance and disease), are also important considerations in modeling the specific relationships between light availability at any given depth in the water column and seagrass production. Cultural eutrophication of coastal ecosystems in South Florida not only has the potential for affecting light attenuation in the water column through the stimulation of phytoplankton biomass, but can negatively impact light availability for seagrass communities by increasing the density of epiphyte populations (Tomasko \& LaPointe 1991). Similarly, the putative role of human diversion of natural freshwater inflows to Florida Bay in stimulating hypersaline conditions has a direct bearing on the structure and dynamics of both planktonic and benthic primary production. Prolonged hypersaline conditions in Florida Bay have been implicated as a major factor in the relative success of planktonic cyanobacteria, like Synechococcus, and the demise of certain seagrass species. It is likely that the effects of light limitation operate synergistically with other environmental factors, like hypersalinity and eutrophication, in dictating the character of estuarine ecosystems such as Florida Bay. 
Acknowledgements. The authors thank Frederick Aldridge and Mark Brenner for their review of the manuscript and Phyllis Hansen and Beate Rueter for their assistance in the analysis of samples. The research was supported by a grant from Florida Sea Grant, No. PD-93-6. Publication R-03780 of the Florida Agricultural Experiment Station Journal Series.

\section{LITERATURE CITED}

APHA (1989) Standard methods for the examination of water and wastewater, 17 th edn. American Public Health Association, Washington, DC

Armentano T, Ortner P, Robblee M, Thompson N, Rudnick D, Hunt J, Ley J (1994) Interagency Florida Bay science plan. Everglades National Park, Homestead, FL

Arvola L (1984) Vertical distribution of primary production and phytoplankton in two small lakes with different humus concentration in southern Finland. Holarct Ecol 7: 390-398

Bannister TT (1974) Production equation om terms of chlorophyll concentration, quantum yield, and upper limit to production. Limnol Oceanogr 19:1-12

Beaver JR, Crisman TL (1991) Importance of latitude and organic color on phytoplankton primary productivity in Florida lakes. Can J Fish Aquat Sci 48:1145-1150

Boesch DF, Armstrong NE, D'Elia CF, Maynard NG, Paerl HW, Williams SL (1993) Deterioration of the Florida Bay ecosystem: an evaluation of the scientific evidence. Report to the Interagency Working Group on Florida Bay, US Dept of Commerce, Washington, DC

Borum J (1985) Development of epiphytic communities on eelgrass (Zostera marina) along a nutrient gradient in a Danish estuary. Mar Biol 87:211-218

Bulthuis DA, Woelkerling WJ (1983) Biomass accumulation and shading effects of epiphytes on leaves of the seagrass, Heterozostera tasmanica, in Victoria, Australia. Aquat Bot 16:137-148

Cadee GC, Hegeman J (1979) Phytoplankton primary production, chlorophyll and composition in an inlet of the western Wadden Sea (Marsdiep). Neth J Sea Res 13: $224-241$

Cloern JE (1987) Turbidity as a control on phytoplankton biomass and productivity in estuaries. Cont Shelf Res 7: $1367-1381$

Colijn F (1982) Light absorption in the waters of the EmsDollard Estuary and its consequences for the growth of phytoplankton and microphytobenthos. Neth J Sea Res 15:196-216

Dawes C, Tomasko D (1988) Depth distribution of Thalassia testudinum in two meadows on the west coast of Florida, a difference in effect of light availability. PSZN 1: Mar Ecol 9:123-130

Day JW Jr, Madden CJ, Ley-Lou F, Wetzel RL, Navarro AM (1988) Aquatic primary productivity in Términos lagoon region. In: Yánez-Arancibia A, Day JW Jr (eds) Ecology of coastal ecosystems in the southern Gulf of México - the Términos lagoon region. Universidad Nacional Autónoma de México, Mexico City, p 221-235

Dennison WC (1987) Effects of light on seagrass photosynthesis, growth and depth distributions. Aquat Bot 27:15-26

Duarte CM (1991) Seagrass depth limits. Aquat Bot 40: 363-377

Dufour P, Slepoukha M (1981) Etude de la fertilité d'une lagune tropicale de Côte d'Ivoire au moyen de tests biologiques sur populations phytoplanctoniques naturelles. Rev Hydrobiol Trop 14:103-114
Fourqurean JW, Jones RD, Zieman JC (1993) Processes influencing water column nutrient characteristics and phosphorus limitation of phytoplankton biomass in Florida Bay, FL, USA: inferences from spatial distributions. Estuar coast Shelf Sci 36:295-314

Fourqurean JW, Zieman JC, Powell GVN (1992) Phosphorus limitation of primary production in Florida Bay: evidence from C:N:P ratios of the dominant seagrass Thalassia testudinum. Limnol Oceanogr 37:162-171

Gallegos CL, Correll DL, Pierce JW (1990) Modelling spectral diffuse attenuation, absorption, and scattering coefficients in a turbid estuary. Limnol. Oceanogr. 35:1486-1502

Ganf, G. G. (1980). Factors controlling the growth of phytoplankton in Mount Bold Reservoir, South Australia. Aust Water Res Counc Tech Pap 48

Geddes MC (1984) Limnology of Lake Alexandrina, River Murray, South Australia and the effects of nutrients and light on the phytoplankton. Aust J mar Freshwat Res 35: $399-415$

Goldsborough W, Kemp M (1988) Light responses of a submersed macrophyte: implications for survival in turbid tidal waters. Ecology 69:1775-1786

Grandberg K. Harjula H (1982) Nutrient dependence of phytoplankton production in brown-water lakes with special reference to Lake Paijanne. Hydrobiologia 86:129-132

Harding LW Jr, Meeson BW, Fisher TR Jr (1986) Phytoplankton production in two East Coast estuaries: photosynthesis-light functions and patterns of carbon assimilation in Chesapeake and Delaware Bays. Estuar coast Shelf Sci 23:737-806

Hodgkin EP, Birch PB (1986) No simple solutions: proposing radical management options for a eutrophic estuary. Mar Pollut Bull 17:399-404

Joint IR, Pomroy AJ (1981) Primary production in a turbid estuary. Estuar coast Shelf Sci 13:303-316

Kenworthy WJ, Haunert DE (1991) The light requirements of seagrasses. Proceedings of a workshop to examine the capability of water quality criteria, standards and monitoring programs to protect seagrasses. NOAA Technical Memorandum, NMFS SEFC-287, p 85-94

Kirk JTO (1980) Spectral absorption properties of natural waters: contribution of the soluble and particulate fractions to light absorption in some inland waters of southeastern Australia. Aust J mar Freshwat Res 31:287-296

Kirk JTO (1994) Light and photosynthesis in aquatic ecosystems, 2nd edn. Cambridge University Press, Cambridge

Knoppers B, Kjerfve B, Carmouze JP (1991) Trophic state and water turn-over time in six choked coastal lagoons in Brazil. Biogeochemistry 16:149-166

LaPointe BE, Clark MW (1992) Nutrient inputs from the watershed and coastal eutrophication in the Florida Keys. Estuaries 15:465-476

Libes M (1986) Productivity-irradiance relationship of Posidonia oceanica and its epiphytes. Aquat Bot 26:285-306

Limon JG, Lind OT, Vodopich DS, Doyle R, Trotter BG (1989) Long- and short-term variation in the physical and chemical limnology of a large, shallow, turbid lake (Lake Chapala, Mexico). Arch Hydrobiol (Suppl) 83:57-81

Lorenzen CJ (1972) Extinction of light in the ocean by phytoplankton. J Cons 34:262-267

Malone TC (1977) Environmental regulation of phytoplankton productivity in the lower Hudson Bay Estuary. Estuar coast mar Sci 5:157-171

McPherson BF. Miller RL (1987) The vertical attenuation of light in Charlotte Harbor, a shallow, subtropical estuary, south-western Florida. Estuar coast Shelf Sci 25:721-737 
Morris LJ, Tomasko DA (1993) Proceedings and conclusions of workshops on submerged aquatic vegetation and photosynthetically active radiation. Special publication SJ93-SP13. St. Johns River Water Management District, Palatka, FL

Nielsen SL, Borum J, Geertz-Hansen O. Sand-Jensen J (1989) Marine bundplanters dybdegraense. Vand Miljø 5: $217-220$

Oertal GF, Dunstan WM (1981) Suspended-sediment distribution and certain aspects of phytoplankton production off Georgia, USA. Mar Geol 40:171-197

Oliver RL (1981) Factors controlling phytoplankton seasonal succession in Mt. Bold Reservoir, South Australia. PhD dissertation, University of Adelaide

Oswald WJ, Gataas HB (1957) Photosynthesis in sewage treatment. Trans. Am Soc Civil Eng 122:73-97

Pennock JR, Sharp JH (1986) Phytoplankton production in the Delaware Estuary: temporal and spatial variability. Mar Ecol Prog Ser 34:143-155

Phlips EJ, Aldridge FJ, Hanlon C (1995a) Factors limiting phytoplankton standing crop in a sub-tropical lake (Lake Okeechobee, FL, USA). Arch Hydrobiol Beih Ergebn Limnol 45:137-155

Phlips EJ, Aldridge FJ, Hansen P, Zimba PV, Ihnat J, Conroy M, Ritter R (1993) Spatial and temporal variability of trophic state parameters in a shallow subtropical lake (Lake Okeechobee, Florida, USA). Arch Hydrobiol 128:437-458

Phlips EJ, Aldridge FJ, Schelske CL, Crisman TL (1995b) Relationships between light availability, chlorophyll a and tripton in a large shallow sub-tropical lake. Limnol Oceanogr 40(2) (in press)

Phlips EJ, Badylak S (1995) Spatial variability in phytoplankton standing crops and composition in Florida Bay, Florida. Bull mar Sci 57(3) (in press)

Phlips EJ, Zeman C, Hansen P (1989) Growth, photosynthesis, nitrogen fixation and carbohydrate production by a unicellular cyanobacterium, Synechococcus sp. (Cyanophyta). J Appl Phycol 1:137-145

Platt T, Jass by AD (1976) The relationship between photosynthesis and light for natural assemblages of coastal marine phytoplankton. J Phycol 12:421-430

Powell GV, Powell N, Judson Kenworthy W, Fourqurean JW (1989) Experimental evidence for nutrient limitation of seagrass growth in a tropical estuary with restricted circulation. Bull mar Sci 44:324-340

This article was submitted to the editor
Robblee MB, Barber TB, Carlson PR Jr, Durako MJ, Fourqurean JW, Muehstein LM, Porter D, Yabro LA, Zieman RT, Zieman JC (1991) Mass mortality of the tropical sea. grass Thalassia testudinum in Florida Bay (USA). Mar Ecol Prog Ser 71:297-299

Sand-Jensen K (1977) Effect of epiphytes on eelgrass photosynthesis. Aquat Bot 3:55-63

SAS (1989) SAS for PC version 6.04. SAS Institute, Cary, NC

Silberstein K, Chiffings A, McComb A (1986) The loss of seagrass in Cockburn Sound, Western Australia. III. The effect of epiphytes on productivity of Posidonia australia Hook. F. Aquat Bot 24:355-371

Sorensen J (1993) The management of enclosed coastal water bodies: the need for a framework for international information exchange. In: Sorensen $J$, Gable $F$, Bandarin $F$ (eds) The management of coastal lagoons and enclosed bays. American Society of Civil Engineers, New York, $p$ $1-18$

Stefan H, Skoglund T, Megard RO (1976) Wind control of algal growth in eutrophic lakes. Am Soc Civ Env Engr Div 102:1201-1213

Tomasko DB, Lapointe B (1991) Productivity and biomass of Thalassia testudinum as related to water column nutrient availability and epiphyte levels: field observations and experimental studies. Mar Ecol Prog Ser 75:9-17

Vant WN (1990) Causes of light attenuation in nine New Zealand estuaries. Estuar coast Shelf Sci 31:125-137

Vincente VP, Rivera JA (1982) Depth limits of the seagrass Thalassia testudinum (Konig) in Jobos and Guayanilla Bays, Puerto Rico. Caribb J Sci 17:73-79

Walmsley RD (1978) Factors governing turbidity in a South African reservoir. Verh int Verein theor angew Limnol 20: $1684-1689$

Wanless HR, Tagett MG (1989) Origin, growth and evolution of carbonate mudbanks in Florida Bay. Bull mar Sci 44: $454-489$

Ward LG, Kemp WM, Boynton WR (1984) The influence of waves and seagrass communities on suspended particles in an estuarine embayment. Mar Geol 59:85-103

Wolfsy SC (1983) A simple model to predict extinction coefficients and phytoplankton biomass in eutrophic waters. Limnol Oceanogr 28:1144-1155

Zieman JC, Fourqurean JW, Iverson RL (1989) Distribution, abundance and productivity of seagrasses and macroalgae in Florida Bay. Bull mar Scl 44:292-311

Manuscript first received: November 2, 1994

Revised version accepted: May 18, 1995 